\title{
Assessment of the relationship between aortic pulse wave velocity and aortic arch calcification
}

\author{
Aort nabız dalgası hızı ile aort yayı kalsifikasyonu arasındaki ilişkinin \\ değerlendirilmesi
}

\author{
Serkan Öztürk, M.D., " * Davut Baltacı, M.D.," Suzi Selim Ayhan, M.D.," \\ İsmet Durmuş, M.D., ${ }^{*}$ Ömer Gedikli, M.D.,, ${ }^{*}$ Mehmet Soytürk, M.D., ${ }^{\dagger}$ \\ Mehmet Yazıcı, M.D.," Şükrü Çelik, M.D.§ \\ "Department of Cardiology, Abant Izzet Baysal University, Faculty of Medicine, Bolu; \\ "Department of Family Medicine, Düzce University Faculty of Medicine, Düzce; \\ Departments of ${ }^{*}$ Cardiology, ${ }^{\dagger}$ Radiology, Karadeniz Technical University Faculty of Medicine, Trabzon; \\ \$Department of Cardiology, Ahi Evren Cardiovascular and Thoracic Surgery Training and Research Hospital, Trabzon
}

\section{ABSTRACT}

Objectives: We aimed to assess arterial stiffness parameters and to investigate the relationship between these parameters and aortic calcification in patients with aortic arch calcification and without symptomatic atherosclerotic disease.

Study design: The population of this study consisted of 41 patients with aortic arch calcification verified by chest X-ray (group I, 17 males, mean age $70 \pm 5$ years) and individuals without aortic arch calcification (group II, 17 males, mean age $68 \pm 6$ years). Subjects with symptomatic or known vascular disease were excluded from the study. The arterial stiffness parameters of all subjects were measured noninvasively with a SphygmoCor device. Aortic pulse wave velocity (PWV), augmentation pressure (AP), augmentation index (Alx) and heart rate normalized augmentation index (Alx@75) were used as parameters of arterial stiffness.

Results: The two groups were compared according to demographic characteristics, medications currently being taken, and levels of serum lipids. There was no significant difference between the groups. AP in group I was significantly higher than that of group II ( $p=0.002)$. Alx and Alx@75 were similar in both groups. Aortic PWV of group I was significantly higher than that of group II $(p<0.0001)$.

Conclusion: According to the results of this study, the presence of aortic calcification, verified by chest radiography, was associated with increased aortic PWV.

\section{ÖZET}

Amaç: Semptomlu aterosklerotik hastalı̆ıı olmayan hastalarda arteryel sertlik parametreleri ile aort kalsifikasyonu arasındaki ilişkiyi incelemeyi amaçladık.

Çalışma planı: Çalışma popülasyonu göğüs grafisinde aort yayı kalsifikasyonu olan 41 hasta (grup I, 17 erkek, ortalama yaş $70 \pm 5$ yıl) ve kalsifikasyonu olmayan yaş ve cinsiyet eşleştirilmiş 41 kişiden (grup II, 17 erkek, ortalama yaş $68 \pm 6$ yıl) oluşturuldu. Semptomlu veya bilinen vasküler hastalığı olanlar çalışmadan dışlandı. Tüm bireylerin arteryel sertlik parametreleri SphygmoCor cihazı ile ölçüldü. Aort nabzı dalga hızı (PWV), augmentasyon basıncı (AP), augmentasyon indeksi (Alx) ve kalp hızına göre düzeltilmiş augmentasyon indeksi (Alx@75) arteryel sertlik parametreleri olarak değerlendirildi.

Bulgular: İki grup demografik özellikler, ilaç kullanımı ve serum lipit düzeyleri açısından karşılaştıııldı, gruplar arasında anlamlı fark yoktu. AP grup l'de grup Il'ye göre anlamlı ola-

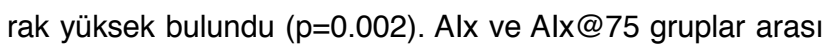
benzerdi. Aort PWV'si grup I de grup II'ye göre anlamlı olarak yüksek bulundu $(p<0.0001)$.

Sonuç: Bu çalışmanın bulgularına göre göğüs grafisinde tespit edilen aort yayı kalsifikasyonu artmış aort nabzı dalga hızı ile ilişkilidir.

Presented at the 27th National Cardiology Congress (October 27-30, 2011, Istanbul, Turkey).

Received: June 05, 2012 Accepted: August 10, 2012

Correspondence: Dr. Serkan Öztürk. Abant İzzet Baysal Üniversitesi Tıp Fakültesi, Kardiyoloji Bölümü, 14280 Gölköy, Bolu, Turkey. Tel: +90 374 - 2534656 e-mail: drserkan69@hotmail.com 
A rterial stiffness is a sign of aging that develops as a result of various diseases, including atherosclerosis, diabetes mellitus (DM), and chronic renal disease. In addition, it indicates an increased risk of cardiovascular disease. ${ }^{[1]}$ Although cellular and structural features can predispose a patient to arterial stiffness and have been shown to accelerate atherosclerosis in arterial vessels, there are few studies examining the relationship between arterial stiffness and atherosclerosis. ${ }^{[2]}$ Increased arterial stiffness and wave reflection values can result in increased central blood pressure, which is associated with cardiovascular events such as stroke and myocardial infarction. In previous epidemiological studies, pulse wave velocity (PWV) has been shown to be an independent predictor of cardiovascular events. ${ }^{[3]} \mathrm{PWV}$ is a simple, reliable, reproducible, and noninvasive method that is often used for evaluating arterial stiffness.

Calcium accumulation on the walls of large arteries has long been recognized as having a role in the development of adverse cardiovascular events. Calcification of the aortic arch via chest X-ray, valvular calcification via echocardiography, or calcification of the carotid artery and vertebral arteries via computed tomography (CT) are considered to be markers of vascular atherosclerosis. One large study reported that calcium deposition in both non-coronary and coronary arteries indicated the extent of atherosclerotic lesions and could be a subclinical marker of cardiovascular disease. ${ }^{[4]}$

The current study was designed to investigate the correlations between arterial stiffness and the presence of aortic arch calcification in patients with aortic calcification on posterior-anterior (PA) chest X-ray.

\section{PATIENTS AND METHODS}

\section{The study design}

This cross-sectional, case-controlled study was conducted at Karadeniz Technical University Faculty of Medicine between March 2008 and March 2009. Patients with abnormal sinus rhythm, malignant hypertension $(>180 / 110 \mathrm{mmHg})$, known connective tissue disease, valvular or congenital heart disease, peripheral arterial disease, coronary heart disease (e.g., myocardial infarction, angina, or previous coronary angioplasty or coronary artery bypass graft surgery with a history of nitrate use), cerebrovascular disease (e.g., stroke, transient ischemic attack, or a history of carotid endarterectomy), chronic obstructive pulmonary disease, aortic wall disease (e.g., Marfan syndrome or aneurysm), an active infectious or inflammatory disease, and malig-

Abbreviations:
$\begin{array}{ll}\text { AIx } & \text { Augmentation index } \\ A P & \text { Augmentation pressure } \\ B M I & \text { Body mass index } \\ C T & \text { Computed tomography } \\ D B P & \text { Diastolic blood pressure } \\ D M & \text { Diabetes mellitus } \\ P A & \text { Posterior-anterior } \\ P W V & \text { Pulse wave velocity } \\ S B P & \text { Systolic blood pressure }\end{array}$
nancies were excluded since these conditions could affect the arterial stiffness parameters. Subjects were assigned to either the study group or to the control group. The study group included those patients with aortic calcification verified by chest X-ray, while the control group consisted of patients who had no aortic calcification.

\section{Study population}

A total of 177 consecutive patients with aortic calcification verified by chest X-ray were included in the study. One hundred thirty six of these patients were excluded from the study. A total of 41 patients with aortic calcification were assigned to the study group (17 males; mean age, $70 \pm 5$ years). The control group consisted of 41 subjects ( 17 males; mean age, $68 \pm 6$ years) matched according to age, smoking status, and the presence of hypertension or DM.

\section{Evaluation of cardiovascular risk factors}

Information related to smoking status, age, the presence of ischemic heart disease, hypertension, DM, stroke, or peripheral vascular disease was obtained from hospital records and/or patient reports. Arterial blood pressure measurements were taken twice with 5 minute intervals from the right arm in the sitting position. According to the report of the 7th Joint National Committee (JNC), patients having either systolic blood pressure (SBP) $\geq 140 \mathrm{mmHg}$ or diastolic blood pressure (DBP) $\geq 90 \mathrm{mmHg}$ were defined as having hypertension. ${ }^{[5]}$ Patients were defined as having diabetes if they had a fasting glucose level of $\geq 126 \mathrm{mg} / \mathrm{dl}$ or were undergoing pharmacological treatment in the area of diabetes. Each subject was classified as either a current smoker or nonsmoker, and the body mass index (BMI) of each subject was calculated as weight $(\mathrm{kg}) /(\text { height }[\mathrm{m}])^{2}$. Obesity was defined as a BMI $\geq 30$ $\mathrm{kg} / \mathrm{m}^{2}$. Dyslipidemia was defined as having a total cholesterol level $>200 \mathrm{mg} / \mathrm{dl}$, low-density lipoprotein (LDL) cholesterol $>160 \mathrm{mg} / \mathrm{dl}$, and high-density lipo- 
protein (HDL) cholesterol $<40 \mathrm{mg} / \mathrm{dl}$ for men and $<50$ $\mathrm{mg} / \mathrm{dl}$ for women. ${ }^{[6]}$

\section{Chest-X ray and detection of aortic arch calcification}

A posterior-anterior chest- $X$ ray was taken with the patient holding his/her breath and standing $2 \mathrm{~m}$ away from the X-ray tube. All chest films were evaluated by two radiologists. Aortic arch calcification was defined as the presence of a curvilinear density along the $\operatorname{arch}{ }^{[7]}$

\section{Measurement of arterial stiffness parameters}

Arterial stiffness was measured using a SphygmoCor device (AtCor Medical, Sydney, Australia) according to the manufacturer's instructions. ${ }^{[8,9]}$ Each patient's gender, age, height, weight, and arterial blood pressure were entered into the SphygmoCor software program. All measurements were taken by the same person with each patient in a supine position after a 5-min acclimation period in a room maintained at $23-24^{\circ} \mathrm{C}$. Radial artery pressure waveforms were recorded at the wrist using applanation tonometry with a high-fidelity micro-manometer (Millar Instruments, Houston, TX). ${ }^{[8,9]}$ After 20 sequential waveforms had been acquired and averaged, a validated, generalized mathematical transfer function was used to synthesize the corresponding central aortic pressure waveform. ${ }^{[8]}$ The point where the incident and reflected waves merged (the inflection point) was identified on the generated aortic pressure waveform.

Augmentation pressure (AP) was defined as the maximum SBP subtracted by the pressure at the inflection point. The augmentation index (AIx) was defined as the AP divided by the pulse pressure and was expressed as a percentage. Larger AIx values indicate either an increased wave reflection from the periphery or an earlier return of the reflected wave as a result of an increased PWV (attributable to increased arterial stiffness). The AIx is dependent upon the elastic properties of the entire arterial tree (elastic and muscular arteries). Because the AIx is influenced by heart rate, a normalized index for a heart rate of 75 bpm (AIx@75) was used in accordance with the report of Wilkinson et al. ${ }^{[10]}$ The accuracy of the values obtained by the SphygmoCor device is indicated by a percentage. Since $>80 \%$ is generally accepted as a high-quality recording, we applied this criterion to our study.

Following radial artery pulse wave analysis, an electrocardiographic (ECG) device was immediately connected for PWV measurement. The aortic PWV was determined by the foot-to-foot method using the SphygmoCor system (AtCor Medical). ${ }^{[8]}$ Consecutive registrations of the carotid and femoral artery pulse waves are electrocardiogram-gated, which allows the time shift between the appearance of a wave at the first and second sites to be calculated. For the aortic PWV, the carotid artery pulse wave was recorded with the ECG followed by the recording of the femoral artery pulse wave. The distance between the two sites was measured to determine the aortic PWV in $\mathrm{m} / \mathrm{s}$. The average of measurements taken over a period of 8 s (9-10 cardiac cycles) was calculated after the exclusion of extreme values. ${ }^{[8,9]}$

\section{Statistical analysis}

Continuous variables were expressed as means \pm standard deviations (SD) and categorical variables were expressed as percentages. Comparisons of the categorical and continuous variables between the groups were performed using chi-square tests and unpaired t-tests, respectively. Normality of the continuous variables was determined by the Kolmogorov-Smirnov test. Logistic regression analyses were used to assess the relationships between arterial stiffness parameters (PWV, AIx@75, AP, aortic mean pressure), age, systolic and diastolic blood pressure, and aortic arch calcification. $\mathrm{P}$ values less than 0.05 were considered to be statistically significant. An SPSS software program (14.0, Inc., Chicago, Illinois) was used for all statistical analyses.

\section{RESULTS}

Patient demographics, laboratory analyses, and medication history are presented in Table 1. There were no significant differences between the ages, SBP, and DBP of the groups $(\mathrm{p}=0.162, \mathrm{p}=0.097$ and $\mathrm{p}=0.075$, respectively). BMI, heart rate, SBP, DBP, lipid parameters, frequency of DM, hypertension, and smoking were similar between the two groups. Although not significant, the SBP values of the group with aortic arch calcification tended to be higher.

Arterial stiffness parameters of both groups are shown in Table 2. Although systolic pressures obtained from the SphygmoCor were similar in both groups $(\mathrm{p}=0.062)$, DBP were significantly different $(p=0.042)$. Heart rate augmentation-adjusted index 
Table 1. Patient demographics, laboratory characteristics, and medications

\begin{tabular}{|c|c|c|c|c|c|c|c|}
\hline & \multicolumn{3}{|c|}{$\begin{array}{l}\text { Aortic calcification }(+) \\
\qquad(\mathrm{n}=41)\end{array}$} & \multicolumn{3}{|c|}{$\begin{array}{l}\text { Aortic calcification }(-) \\
\qquad(n=41)\end{array}$} & \multirow[t]{2}{*}{$p$} \\
\hline & $\mathrm{n}$ & $\%$ & Mean \pm SD & $\mathrm{n}$ & $\%$ & Mean \pm SD & \\
\hline Age & & & $70 \pm 6$ & & & $68 \pm 6$ & NS \\
\hline Gender (male) & 17 & 41 & & 17 & 41 & & NS \\
\hline Hypertension & 33 & 80 & & 29 & 70 & & NS \\
\hline Diabetes mellitus & 5 & 12 & & 4 & 10 & & NS \\
\hline Obesity (BMI $\geq 30)$ & 12 & 29 & & 14 & 34 & & NS \\
\hline Cigarettes & 4 & 9 & & 5 & 12 & & NS \\
\hline $\mathrm{BMI}\left(\mathrm{kg} / \mathrm{m}^{2}\right)$ & & & $28 \pm 4$ & & & $30 \pm 5$ & NS \\
\hline Heart rate & & & $69 \pm 10$ & & & $67 \pm 11$ & NS \\
\hline $\mathrm{SBP}(\mathrm{mmHg})$ & & & $134 \pm 13$ & & & $129 \pm 13$ & NS \\
\hline $\mathrm{DBP}(\mathrm{mmHg})$ & & & $82 \pm 7$ & & & $79 \pm 9$ & NS \\
\hline LDL (mg/dl) & & & $121 \pm 21$ & & & $132 \pm 40$ & NS \\
\hline $\mathrm{HDL}(\mathrm{mg} / \mathrm{dl})$ & & & $47 \pm 12$ & & & $46 \pm 8$ & NS \\
\hline Total cholesterol (mg/dl) & & & $182 \pm 32$ & & & $199 \pm 44$ & NS \\
\hline Triglycerides (mg/dl) & & & $136 \pm 58$ & & & $151 \pm 74$ & NS \\
\hline Aspirin & 19 & & & 13 & & & NS \\
\hline Beta-blocker & 6 & & & 3 & & & NS \\
\hline ACE inhibitor & 12 & & & 9 & & & NS \\
\hline ARB & 11 & & & 14 & & & NS \\
\hline Diuretic & 7 & & & 6 & & & NS \\
\hline Calcium channel blocker & 4 & & & 3 & & & NS \\
\hline
\end{tabular}

NS: Non-significant; BMI: Body mass index; SBP: Systolic blood pressure; DBP: Diastolic blood pressure; LDL: Low density lipoprotein; HDL: High density lipoprotein; ACE: Angiotensin converting enzyme; ARB: Angiotensin receptor blocker.

(Alx@75) was similar in both groups ( $\mathrm{p}=0,755)$, but PWV was significantly $(\mathrm{p}=0.001)$ higher in the study group (Fig. 1). Logistic regression analyses were performed to investigate the independent markers of aortic arch calcification. Arterial stiffness parameters (PWV, AIx@75, aortic mean pressure) and clinical parameters (such as age, BMI, SBP and DBPs and aortic arch calcification) were included in the analy- sis. As a result, only aortic PWV was an independent predictor of the presence of aortic calcification (Table 3).

\section{DISCUSSION}

In the current study, we evaluated the relationship between aortic arch calcification and arterial stiffness

Table 2. The relationship between arterial stiffness parameters and aortic arch calcification

\begin{tabular}{lccc}
\hline & $\begin{array}{c}\text { Aortic calcification }(+) \\
(\mathrm{n}=41)\end{array}$ & $\begin{array}{c}\text { Aortic calcification }(-) \\
(\mathrm{n}=41)\end{array}$ & $p$ \\
\hline Central aortic pressure & & & $120 \pm 13$ \\
$\quad$ Systolic $(\mathrm{mmHg})$ & $126 \pm 13$ & $79 \pm 10$ & 0.062 \\
Diastolic $(\mathrm{mmHg})$ & $83 \pm 7$ & $10 \pm 1$ & 0.047 \\
Pulse wave velocity $(\mathrm{m} / \mathrm{s})$ & $13 \pm 2$ & $28 \pm 9$ & $<0.001$ \\
Augmentation index normalized to heart rate & $29 \pm 10$ & & 0.755 \\
\hline
\end{tabular}




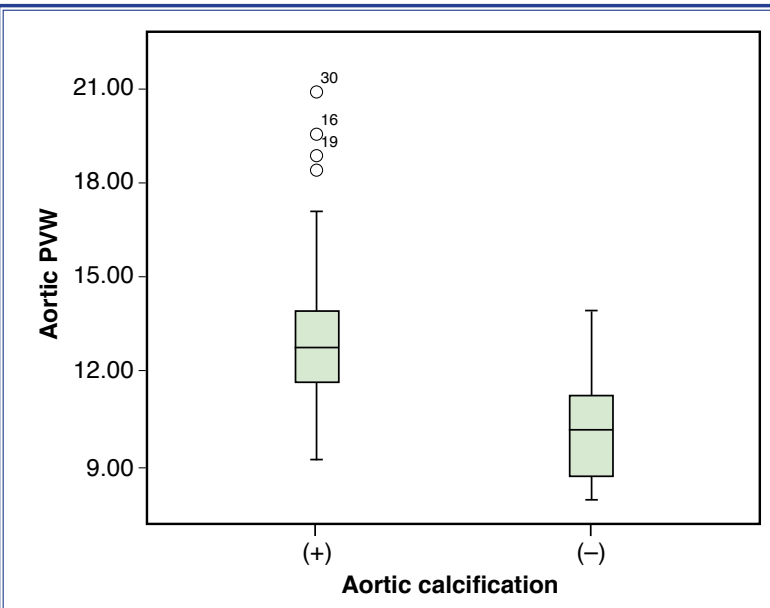

Figure 1. There is a significant relationship between aortic calcification and aortic PWV.

in patients with no clinical evidence of atherosclerotic disease. The AIx@75 was similar in both groups, but the PWV was significantly higher in the study group. Although the aortic PWV was independently correlated with the presence of aortic arch calcification, there was no significant correlation between the normalized heart rate(AIx@75) and aortic arch calcification.

In a recent study, McEniery et al. ${ }^{[11]}$ reported that aortic calcification had a significant positive association with aortic PWV, but it was not related to the AIx. Similarly, we detected a significant relationship between aortic calcification and the aortic PWV, but not with the AIx@75. Interestingly, Raggi et al. ${ }^{[12]}$ reported that the abdominal, but not the thoracic calcium score was independently related to aortic stiffness in hemodialysis patients. Here, abdominal calcification was assessed by standard radiography, while tho- racic deposition was quantified by electron beam CT, which is an expensive and sophisticated method. In our study, aortic calcification was evaluated by chest $\mathrm{X}$-ray, which is commonly used in clinics and is easily interpreted by most physicians. In another small study of healthy Japanese subjects, a relationship was reported between the brachial-ankle PWV and the length of the calcified abdominal aorta on standard radiographs. ${ }^{[13]}$ However, that study was limited in that data on the aortic PWV, which is the gold standard for the measurement of arterial stiffness, were not available.

The Calcification Outcome in Renal Disease (CORD) study was the first large-scale clinical study to assess aortic calcification, PWV, and AIx of dialysis patients concurrently using widely available and relatively low-cost methods. CORD data was used to evaluate whether these surrogate measures for cardiovascular disease risk (aortic calcification, PWV, and AIx) provide complementary or overlapping information. ${ }^{[14]}$ The differences in factors influencing PWV and AIx and their individual relationships with aortic calcification suggest that these three markers are complementary, rather than redundant to each other. ${ }^{[14]}$ In our study, consistent with previous studies, patients with aortic calcification had higher aortic PWV than healthy individuals. ${ }^{[15-17]} \mathrm{PWV}$ does not always change in parallel with the AIx. Aortic PWV is affected by structural changes, while the AIx is mostly affected by endothelial function. ${ }^{[11-14]}$ Also, as aortic calcification impairs the structural properties of the aorta, it is possible that PWV is initially affected by aortic calcification. However, increased cytokine and matrix metalloproteinase levels, the presence of in-

$\begin{aligned} & \text { Table 3. The relationship between arterial stiffness parameters, age, BMI, SBP, DBP, and } \\
& \text { aortic arch calcification via multivariate linear regression analysis }\end{aligned}$
\begin{tabular}{lccc}
\hline & Odds ratio & $95 \% \mathrm{Cl}$ & $p$ \\
\hline Age & 1.028 & $0.879-1.201$ & 0.732 \\
Body mass index & 0.874 & $0.736-1.037$ & 0.122 \\
Systolic blood pressure & 0.960 & $0.876-1.052$ & 0.386 \\
Diastolic blood pressure & 0.967 & $0.846-1.107$ & 0.628 \\
Aortic mean pressure & 1.093 & $0.952-1.254$ & 0.206 \\
Alx@75 & 0.913 & $0.827-1.009$ & 0.075 \\
PWV & 2.137 & $1.390-3.285$ & $\mathbf{0 . 0 0 1}$ \\
\hline
\end{tabular}

BMI: Body mass index; SBP: Systolic blood pressure; DBP: Diastolic blood pressure; Cl: Confidence interval; Alx@75: Normalized for heart rate augmentation index; PWV: Pulse wave velocity. 
flammation, and arterial stiffness also play important roles in the development of aortic calcification. ${ }^{[18,19]}$ More comprehensive studies are needed to assess the relationship between the AIx and PWV. Both aortic calcification and the aortic PWV are associated with coronary artery disease and cardiovascular mortality. ${ }^{[4,16,17]}$ Aortic PWV is an independent indicator of allcause mortality and mortality due to cardiovascular causes. ${ }^{[15-20]}$ Additionally, peripheral vascular disease and ischemic stroke have been found to be associated with aortic calcification. ${ }^{[21,22]}$

\section{Limitations}

The exclusive use of PA chest radiography was a limiting factor for the evaluation of aortic calcification, as it can also be detected via lateral chest radiography. An additional limitation of this study was the small number of subjects.

\section{Conclusions}

This study is the first to show a significant association between the presence of aortic arch calcification via chest X-ray and an increased aortic PWV. Also, carotid-femoral PWV measurements were performed using the SphygmoCor device for the first time. According to the results of the current study, aortic PWV is an early indicator of coronary artery disease and is associated with aortic arch calcification.

\section{Conflict-of-interest issues regarding the authorship or article: None declared}

\section{REFERENCES}

1. Vaccarino V, Berger AK, Abramson J, Black HR, Setaro JF, Davey JA, et al. Pulse pressure and risk of cardiovascular events in the systolic hypertension in the elderly program. Am J Cardiol 2001;88:980-6.

2. Safar ME, Levy BI, Struijker-Boudier H. Current perspectives on arterial stiffness and pulse pressure in hypertension and cardiovascular diseases. Circulation 2003;107:2864-9.

3. Asmar R, Benetos A, Topouchian J, Laurent P, Pannier B, Brisac AM, et al. Assessment of arterial distensibility by automatic pulse wave velocity measurement. Validation and clinical application studies. Hypertension 1995;26:485-90.

4. Iribarren C, Sidney S, Sternfeld B, Browner WS. Calcification of the aortic arch: risk factors and association with coronary heart disease, stroke, and peripheral vascular disease. JAMA 2000;283:2810-5.

5. Scuteri A, Brancati AM, Gianni W, Assisi A, Volpe M. Arterial stiffness is an independent risk factor for cognitive impair- ment in the elderly: a pilot study. J Hypertens $2005 ; 23: 1211-$ 6.

6. Celik S, Durmuş I, Korkmaz L, Gedikli O, Kaplan S, Orem C, et al. Aortic pulse wave velocity in subjects with aortic valve sclerosis. Echocardiography 2008;25:1112-6.

7. Jean G, Bresson E, Terrat JC, Vanel T, Hurot JM, Lorriaux $\mathrm{C}$, et al. Peripheral vascular calcification in long-haemodialysis patients: associated factors and survival consequences. Nephrol Dial Transplant 2009;24:948-55.

8. Gedikli O, Kiris A, Ozturk S, Baltaci D, Karaman K, Durmus $\mathrm{I}$, et al. Effects of prehypertension on arterial stiffness and wave reflections. Clin Exp Hypertens 2010;32:84-9.

9. Laurent S, Cockcroft J, Van Bortel L, Boutouyrie P, Giannattasio C, Hayoz D, et al. Expert consensus document on arterial stiffness: methodological issues and clinical applications. Eur Heart J 2006;27:2588-605.

10. Wilkinson IB, MacCallum H, Flint L, Cockcroft JR, Newby DE, Webb DJ. The influence of heart rate on augmentation index and central arterial pressure in humans. J Physiol 2000;525:263-70.

11. McEniery CM, McDonnell BJ, So A, Aitken S, Bolton CE, Munnery M, et al. Aortic calcification is associated with aortic stiffness and isolated systolic hypertension in healthy individuals. Hypertension 2009;53:524-31.

12. Raggi P, Bellasi A, Ferramosca E, Islam T, Muntner P, Block GA. Association of pulse wave velocity with vascular and valvular calcification in hemodialysis patients. Kidney Int 2007;71:802-7.

13. Nakamura U, Iwase M, Nohara S, Kanai H, Ichikawa K, Iida M. Usefulness of brachial-ankle pulse wave velocity measurement: correlation with abdominal aortic calcification. Hypertens Res 2003;26:163-7.

14. Verbeke F, Van Biesen W, Honkanen E, Wikström B, Jensen PB, Krzesinski JM, et al. Prognostic value of aortic stiffness and calcification for cardiovascular events and mortality in dialysis patients: outcome of the calcification outcome in renal disease (CORD) study. Clin J Am Soc Nephrol 2011;6:153-9.

15. Franklin SS, Khan SA, Wong ND, Larson MG, Levy D. Is pulse pressure useful in predicting risk for coronary heart Disease? The Framingham heart study. Circulation 1999;100:35460.

16. Benetos A, Safar M, Rudnichi A, Smulyan H, Richard JL, Ducimetieère $\mathrm{P}$, et al. Pulse pressure: a predictor of long-term cardiovascular mortality in a French male population. Hypertension 1997;30:1410-5.

17. Meaume S, Benetos A, Henry OF, Rudnichi A, Safar ME. Aortic pulse wave velocity predicts cardiovascular mortality in subjects $>70$ years of age. Arterioscler Thromb Vasc Biol 2001;21:2046-50.

18. Qin X, Corriere MA, Matrisian LM, Guzman RJ. Matrix metalloproteinase inhibition attenuates aortic calcification. Arterioscler Thromb Vasc Biol 2006;26:1510-6. 
19. Tomasek JJ, Gabbiani G, Hinz B, Chaponnier C, Brown RA. Myofibroblasts and mechano-regulation of connective tissue remodelling. Nat Rev Mol Cell Biol 2002;3:349-63.

20. Nürnberger J, Keflioglu-Scheiber A, Opazo Saez AM, Wenzel RR, Philipp T, Schäfers RF. Augmentation index is associated with cardiovascular risk. J Hypertens 2002;20:2407-14.

21. Doherty TM, Fitzpatrick LA, Inoue D, Qiao JH, Fishbein MC, Detrano RC, et al. Molecular, endocrine, and genetic mecha- nisms of arterial calcification. Endocr Rev 2004;25:629-72.

22. Peterson LN, Jensen RE, Parnell R. Mechanical properties of arteries in vivo. Circ Res 1960;8:622-39.

Key words: Aorta/physiopathology; blood pressure; calcinosis/complications/physiopathology/radiography; elasticity; hypertension.

Anahtar sözcükler: Aort/fizyopatoloji; kan basıncı; kalsinoz/komplikasyonlar/fizyopatoloji/radyografi; elastisite; hipertansiyon. 